\title{
ALIRAN SESAT DAN GERAKAN BARU KEAGAMAAN (Perspektif UU PNPS No. 1 Tahun 1965 dan Hak Asasi Manusia)
}

\author{
Umi Sumbulah \\ Fakultas Syariah UIN Maulana Malik Ibrahim Malang \\ ummisumbulah@gmail.com
}

\begin{abstract}
One typology of new religious movements in Indonesia based on the essence of teachings was the group which was considered heretical by the competent authorities, namely the Kingdom of God which led by Lia Aminuddin and al -Qiyadah al-Islamiyah led by Ahmad Moshadeq. Under Act No. PNPS 1 In 1965, the two groups were assessed deviant and criminal breaking so that the perpetrator was sentenced to a maximum of 5 years in prison. Considering the provisions contained in the ICCPR which has been ratified by Indonesia, where the law is contrary to the values of human rights which have been adopted in the constitution and legislation that produced the Reform Era. Legislation which is a product of the Old Order law has been used by New Order for restrictions and co-optation to the development of religious freedom and belief in Indonesia.

Salah satu tipologi gerakan baru keagamaan di Indonesia berdasarkan hakikat ajarannya adalah kelompok yang dinilai sesat oleh otoritas berwenang, yakni Kerajaan Tuhan yang dipimpin Lia Aminuddin dan al-Qiyadah al-Islamiyah yang dipimpin Ahmad Moshadeq. Berdasarkan UU PNPS No. 1 tahun 1965, dua kelompok tersebut dinilai sesat dan melanggar pidana sehingga pelakunya dijatuhi hukuman maksimal 5 tahun penjara. Menimbang ketentuan yang terdapat dalam ICCPR yang telah diratifikasi Indonesia, keberadaan UU itu bertentangan dengan nilai-nilai HAM yang telah diadopsi dalam konstitusi dan perundang-undangan yang diproduksi era reformasi. Undang-undang yang merupakan produk hukum Orde Lama tersebut telah digunakan oleh Orde Baru untuk pembatasan dan "kooptasi" terhadap perkembangan kebebasan beragama dan berkeyakinan di Indonesia.
\end{abstract}

Kata Kunci: Aliran sesat, Gerakan baru, HAM

Di Indonesia, terdapat fenomena aliran sesat dan gerakan baru keagamaan (new religious movement/ NRM). Sekte Kerajaan Tuhan pimpinan Lia Aminuddin (Lia Eden), aliran Qur'an Suci, juga al-Qiyadah alIslamiyah pimpinan Ahmad Moshadeq, dapat disebut sebagai contoh adanya gerakan baru keagamaan. Al-Qiyadah al-Islamiyah pimpinan Ahmad Moshadeq yang mengajarkan syahadat baru, nabi baru sesudah Nabi Muhammad SAW, serta tidak mewajibkan shalat, puasa, dan haji bagi anggotanya, dinilai telah menyimpang dari ajaran Islam. Karena itu, Majelis Ulama Indonesia (MUI) telah memfatwa haram dan secara resmi melarang aliran tersebut, pada nomor 4 tahun 2007 yang dikeluarkan pada tanggal 3 Oktober 2007. ${ }^{1}$ Fatwa tersebut kemudian diikuti oleh MUI daerah-daerah di Indonesia, seperti MUI Sumatera Barat, MUI Kabupaten dan Kota Malang, dan MUI Kabupaten Blitar. Pelarangan terhadap aliran ini didasarkan pada hasil rapat koordinasi (rakor) pengawas aliran kepercayaan masyarakat (Pakem) yang diikuti sejumlah instansi, seperti Kementerian Agama, Dinas Kebudayaan, MUI serta kepolisian. Pelarangan itu pada awalnya diberlakukan di seluruh Jakarta, kemudian disusul Depok dan kemudian pelarangan tersebut juga diberlakukan di seluruh Indonesia. Baik pemimpin maupun pengikut

\footnotetext{
${ }^{1}$ Harian Umum Jawa Pos, 30 Oktober 2007.
} 
aliran ini dapat ditindak secara pidana dengan dinyatakan melanggar pasal 156 KUHP dengan ancaman maksimal 5 tahun penjara. ${ }^{2}$

Gerakan baru keagamaan (new religious movement), bisa ditipologikan berdasarkan hakikat ajarannya; kecenderungan pemahamannya, maupun ekspresi keagamaannya. Ditilik dari aspek hakikat ajarannya, gerakan baru keagamaan sebagaimana disebutkan di atas, baik yang memiliki anggota kelompok yang banyak, cukup banyak maupun yang sedikit, gerakan tersebut bisa dikategorikan sebagai gerakan atau ajaran sesat. Dinilainya sesat ajaran kelompok ini misalnya dapat diverifikasi berdasarkan ajaran pokok Islam yang telah diyakini pada umumnya oleh mayoritas umat Islam, seperti pada rukun iman dan rukun Islam. Kelompok tersebut di antaranya aliran Kerajaan Tuhan pimpinan Lia Aminuddin (Lia Eden), aliran Qur'an Suci di Jakarta, dan AlQiyadah al-Islamiyah pimpinan Ahmad Moshadeq. Dari sisi hakikat ajarannya, pada ketiga aliran tersebut terdapat penyimpangan.

Tipologi kedua dari gerakan baru keagamaan bisa ditilik dari sisi ekspresi keagamaan yang cenderung keras. Dari sisi hakikat ajaran agama, sistem keyakinan mereka tidak menyimpang dari keyakinan kelompok Islam mainstream, terutama ditilik dari dua pilar keyakinan pokok, yakni rukun iman dan rukun Islam. Namun ditilik dari konstruksi ideologi mereka berkaitan dengan ideologi jihad dan definisi tentang musuh, mereka cenderung rigid. Terdapat mindset yang tampaknya begitu kuat tentang binner oposition (memposisikan secara berlawanan) antara Islam dan Barat, Islam dan YahudiKristen. Kedua kekuatan ini selalu dihadapkan pada posisi yang bermusuhan. Karena itu, dalam keyakinan ideologis kelompok ini, Barat yang lazim direpresentasikan oleh negaranegara Amerika dan Australia selalu diposisikan sebagai musuh. Bagi mereka, kedua negara ini merupakan biang dari semua kehancuran umat Islam, baik dari sisi moral, ekonomi, sosial maupun politik. Bombing dan terorisme merupakan ekspresi keagamaan kelompok ini, sebagai bentuk perlawanan mereka terhadap apa yang mereka sebut dan

\footnotetext{
${ }^{2}$ Harian Umum Jawa Pos, 31 Oktober 2007
}

definisikan sebagai "musuh." Tipologi kedua dari gerakan baru keagamaan ini bisa dilihat pada kelompok-kelompok Islam tertentu yang mengekspresikan jihad dengan teror dan bombing seperti kelompok Imam Samudera dkk dalam bom Bali, kelompok pengebom JW Marriot dan Ritz Carlton Jakarta dan kelompok-kelompok serupa yang selalu menebar teror ketakutan dan bombing di tempat lain.

Tipologi ketiga dari gerakan baru keagamaan adalah jika ditilik dari aspek kecenderungan pemahaman keagamaan. Kelompok ini memiliki sistem keyakinan yang sama dengan keyakinan kelompok Islam mainstream. Perbedaannya terletak pada bagaimana kelompok ini mensistematisir pengetahuan yang dikonstruksi sedemikian rupa sehingga mengkristal membentuk ideologi tertentu. Ideologi dimaksud digunakan sebagai penuntun dan alat perjuangan mereka dalam upaya meraih citacita. Hanya saja perjuangan kelompok ini cenderung dilakukan secara damai, baik melalui jalur sruktural maupun kultural. Di antara kelompok gerakan baru keagamaan yang bisa dikategorikan pada tipologi ini di antaranya adalah Hizb al-Tahrir, Majelis Mujahidin, Ikhwanul Muslimin, dan Salafi. ${ }^{3}$

\section{Aliran Sesat dan Gerakan Baru Keagamaan Perspektif UU PNPS No. 1 Tahun 1965.}

Dalam beberapa pasal dalam UU PNPS No.1 tahun 1965, disebutkan aturan tentang penodaan agama dan aliran sesat. Di antaranya disebutkan dalam pasal 1, pasal 2 dan pasal 3 untuk hukumannya ${ }^{4}$, sebagaimana terlihat dalam petikan pasal berikut:

\section{Pasal 1:}

"Setiap orang dilarang dengan sengaja di muka umum menceritakan, menganjurkan atau mengusahakan dukungan umum, untuk melakukan penafsiran tentang sesuatu agama yang dianut di Indonesia atau melakukan kegiatan-kegiatan keagamaan yang menyerupai kegiatan-kegiatan

\footnotetext{
3 Umi Sumbulah, Konfigurasi Fundamentalisme Islam (Malang: UIN Malang Press, 2009), h. 14-15.

${ }^{4}$ UU PNPS Nomor 1 tahun 1965 tentang Pencegahan Penyalahgunaan Dan/Atau Penodaan Agama.
} 
keagamaan dari agama itu, penafsiran dan kegiatan mana menyimpang dari pokok-pokok ajaran agama itu’.

Pasal 2:

(1) Barang siapa melanggar ketentuan tersebut dalam pasal 1 diberi perintah dan peringatan keras untuk menghentikan perbuatannya itu di dalam suatu keputusan bersama Menteri Agama, Menteri/Jaksa Agung dan Menteri Dalam Negeri.

(2) Apabila pelanggaran tersebut dalam ayat (1) dilakukan oleh Organisasi atau sesuatu aliran kepercayaan, maka Presiden Republik Indonesia dapat membubarkan Organisasi itu dan menyatakan Organisasi atau aliran tersebut sebagai Organisasi/ aliran terlarang, satu dan lain setelah Presiden mendapat pertimbangan dari Menteri Agama, Menteri/Jaksa Agung dan Menteri Dalam Negeri.

Pasal 3:

"Apabila, setelah dilakukan tindakan oleh Menteri Agama bersama-sama Menteri/Jaksa Agung dan Menteri Dalam Negeri atau oleh Presiden Republik Indonesia menurut ketentuan dalam pasal 2 terhadap orang, Organisasi atau aliran kepercayaan, mereka masih terus melanggar ketentuan dalam pasal 1, maka orang, penganut, anggota dan/atau anggota Pengurus Organisasi yang bersangkutan dari aliran itu dipidana dengan pidana penjara selama-lamanya lima tahun". 5

Dalam konteks penodaan agama dan aliran sesat sebagaimana dimaksud dalam Undangundang di atas, MUI juga telah menetapkan 10 kriteria aliran sesat: 1) mengingkari salah satu rukum iman dan rukun Islam; 2) meyakini atau mengikuti akidah yang tidak sesuai dengan dalil shar'i (al-Qurân dan al-Sunnah); 3) meyakini turunnya wahyu sesudah al-Qurân; 4) mengingkari autentisitas dan kebenaran alQurân; 5) menafsirkan al-Qurân yang tidak berdasar kaidah tafsir; 6) mengingkari

\footnotetext{
${ }^{5}$ Dikutip secara utuh dari UU PNPS Nomor 1 Tahun 1965.
}

kedudukan hadis Nabi sebagai sumber tasyri' Islam; 7) menghina, melecehkan, dan/atau merendahkan nabi dan rasul, mengingkari Nabi Muhammad SAW sebagai nabi dan rasul terakhir, mengubah, menambah dan mengurangui pokok-pokok ibadah yang telah ditetapkan sharî' at; dan 10) mengafirkan sesama muslim tanpa dalil shar'i. ${ }^{6} 10$ kriteria tersebut ditetapkan melalui rapat kerja Nasional (rakernas) MUI 6 Nopember 2007 di Hotel Sari Pan Pasific. Menurut Ichwan Syam, Sekretaris Umum MUI, sejak tahun 1980-an, MUI telah mengeluarkan fatwa 10 aliran sesat, yakni: Inkar al-Sunnah, Ahmadiyah, Islam Jama'ah, Shalat dua bahasa, komunitas Lia Eden, Salamullah dan al-Qiyadah al-Islamiyah. Aliran yang kini juga dalam proses penelitian MUI adalah Wahidiyah -- baik penyiaran maupun perjuangan -- yang berpusat di Jombang dan Kediri, Jawa Timur. ${ }^{7}$

Di samping sejumlah aliran sesat yang telah divonis MUI sebagai aliran sesat di atas, di beberapa daerah juga terdapat kelompokkelompok yang memberikan tafsiran atas Islam semaunya sendiri. Di antaranya adalah yang terjadi di Banten. Kelompok Majelis Ta'lim "Nurul Yakin" pimpinan Juwata yang dianggap sesat. Kelompok ini dinilai sesat misalnya karena mewajibkan puasa 27 hari dan membaca syahadat ulang bagi calon anggota yang ingin bergabung; pasangan suami isteri calon anggota yang sedang berpuasa juga dilarang berhubungan seks pada malam hari; serta menafsirkan al-Qurân semaunya sendiri. Kendati disesalkan oleh ketua MUI Kabupaten Tangerang, Banten, namun perusakan dan amuk massa terhadap rumah Juwata yang dianggap menjadi base camp kelompok tersebut telah terjadi. Meskipun sudah menyatakan taubat, namun Juwata dan 48 pengikutnya berikut rumah base camp-nya tetap menjadi sasaran amuk masa. ${ }^{8}$

Fenomena yang serupa juga terjadi pada kasus Ivan Santoso, yang mengaku dirinya sebagai Isa al-Masih Putera Maryam. Laki-laki asal Cirebon Jawa Barat tersebut memiliki

\footnotetext{
${ }^{6}$ Harian Umum Jawa Pos, 7 Nopember 2007.

7 "MUI Tetapkan 10 Kriteria Aliran Sesat", Harian Jawa Pos, 7 Nopember 2007, h. 3.

8 "Sudah Tobat Tetap Diserbu dan Dibakar", Harian Jawa Pos, 7 Nopember 2007, h. 1.
} 
perilaku aneh semenjak isterinya minta cerai karena ia tidak mampu memberikan nafkah disebabkan putus hubungan kerja (PHK) dari tempat kerjanya. Namun kini Ivan telah bertaubat, yang pertaubatannya juga disaksikan oleh kedua orangtuanya. ${ }^{9}$ Demikian pula kelompok minoritas dalam agama, misalnya Ahmadiyah terus mengalami diskriminasi dan pengawasan oleh negara. Selain itu, kelompok minoritas politik, seperti, mantan tahanan/narapidana politik PKI atau yang didakwa anggota atau simpatisan PKI dan partai-partai kiri terus mengalami pengingkaran hak-hak politik mereka oleh negara.

Dalam konteks di atas, dapat disebut misalnya penolakan Mahkamah Konstitusi (MK) terhadap Judicial Review atas UU/PNPS/1964. Uji materi undang-undang tersebut diajukan oleh Aliansi Kebangsaan untuk Kebebasan Beragama dan Berkeyakinan (AKPBP). Menurut peneliti, UU/PNPS/1964 tentang pencegahan penodaan agama itu masih layak untuk dipertahankan. Hal itu dalam rangka menjaga adanya upaya-upaya yang dapat mengarah kepada penodaan, pelecehan atau penghinaan terhadap agama tertentu, sehingga tidak perlu dicabut. Namun perlu adanya pembatasan-pembatasan secara teknis mengenai misalnya apa yang dimaksud dengan penodaan agama, atau sejauhmana suatu aktivitas dapat dikategorikan sebagai pelecehan atau penodaan agama. Hal ini mengingat istilah tesebut tidak dijelaskan secara lebih rinci dan detail mengenai apa yang dimaksud dengan penodaan agama. Sebagai akibatnya, semua orang dapat mengatakan bahwa perilaku tertentu termasuk atau tidak termasuk dalam kategori penodaan agama. Dalam konteks ini, biasanya penafsiran dan arogansi mayoritas seringkali diposisikan sebagai "hakim" yang mengadili perilaku, aktivitas keagamaan, atau aliran-aliran tertentu yang dianggap berbeda dari arus utama atau mainstream, bahkan acapkali sebagai "pengadil" sekaligus eksekutor bagi kelompok atau aliran tententu sebagai kelompok atau aliran sesat dan sebagainya.

Undang-undang Nomor 1 Penetapan Presiden nomor 1 tahun 1965 adalah salah satu

\footnotetext{
9 “Reportase Sore”, Trans TV, tanggal 31 Juli 2009.
}

Undang-undang yang mengatur mengenai ancaman pidana bagi setiap orang yang dianggap melakukan penodaan terhadap agama. Disebutkan dalam penjelasan Undang Undang ini adalah agama mayoritas yang dipeluk oleh bangsa Indonesia yaitu Islam, Kristen, Katolik, Hindu, Budha dan Konghuchu, meskipun memngkinkan perlindungan bagi agama lain seperti agama Yahudi, Taoism, Shinto, Zarathustrian.

Keberadaan Undang-undang tentang pencegahan penodaan agama ini menimbulkan masalah yang rumit bagi pemeluk keyakinan selain 6 agama mayoritas. Mereka terancam bahkan ada yang sudah terkena sanksi pidana karena memiliki ajaran yang berbeda yang dianggap menyimpang dari ke-enam agama mayoritas. Tempo Interaktif 18 Desember 2009 memberitakan penangkapan Kusmanto Sujono karena meyakini ajaran Sabda Kusuma. Karena oleh MUI dianggap sebagai aliran sesat maka Kusmantopun ditangkap dan ditahan oleh Polres Kudus. Cerita yang sama juga dialami oleh Lia Eden yang harus dipidana selama 2 tahun 6 bulan karena dianggap melakukan penodaan agama pada Juni 2009 lalu, bahkan itu adalah kedua kalinya Lia Eden dipidana dengan tuduhan yang sama.

UU tersebut juga memberikan ruang bagi pemerintah untuk membedakan pemeluk agama yang satu dengan yang lainya. Bagaimana tidak, negara memidanakan pemeluk agama yang dianggap menodai agama tertentu. Padahal menurut hukum setiap orang memiliki kedudukan yang sama. Menurut Frans Magnis Soeseno dan Luthfi Assyaukanie, bahwa negara tidak memiliki hak untuk menyatakan suatu ajaran menyimpang atau tidak menyimpang, sesat atau tidak sesat dan sebagainya. Dalam konteks ini, negara hanya bisa menyebutkan bahwa suatu ajaran atau aliran atau kelompok tersebut berbeda dengan ajaran lainya, atau ajaran yang dianut oleh kelompok mayoritas. Dengan menyatakan sebuah ajaran menyimpang maka berarti bahwa negara dalam posisi tidak netral. Undang-undang ini juga dinilai telah melanggar hak atas kebebasan beragama yang dijamin secara konstitusional terutama oleh pasal 29 UUD 1945, dan sejumlah perundangan lainnya. 


\section{Aliran Sesat dan Gerakan Baru Keagamaan Perspektif HAM}

Sejak "kran" reformasi dibuka, berbagai produk hukum dilahirkan guna memperbaiki kondisi hak asasi manusia di Indonesia, khususnya hak sipil dan politik. Sebagian dari UU tersebut berhubungan langsung dengan HAM, tetapi sebagian lain mempunyai efek tidak langsung bagi penegakan maupun penghormatan terhadap prinsip HAM. Produk hukum dimaksud di antaranya berupa Tap MPR tentang HAM, UU Pers, UU tentang Kemerdekaan Menyampaikan Pendapat (UU Unjuk Rasa), UU HAM (UU No. 39 Tahun 1999), UU Pemilu, UU Parpol, UU Susduk MPR, DPR, dan DPRD, UU Otonomi Daerah, UU ratifikasi Konvensi PBB Menentang Penyiksaan, atau perlakuan atau hukuman lain yang kejam, tidak manusiawi atau merendahkan martabat, UU ratifikasi Konvensi Anti Diskriminasi Rasial. ${ }^{10}$

Melihat sejumlah kasus tentang eksekusi "sesat" pada kelompok tertentu yang muncul dan berkembang di Indonesia, tampaknya menarik dilihat pasal 18 Hak-hak Sipil dan Politik (International Covenant on Civil and Political Rights/ICCPR). Ketentuan mengenai kebebasan beragama dalam konteks ICCPR ini mengandung dua aspek kebebasan sekaligus, yaitu kebebasan beragama atau berkepercayaan dan kebebasan untuk menjalankan agama atau kepercayaannya. Dengan demikian makna pasal ini sesungguhnya adalah melindungi dua aspek kebebasan beragama sekaligus, yakni kebebasan beragama dalam hubungannya dengan keberadaan spiritual seseorang dan hak untuk 'mengeluarkan atau memanifestasikan' keberadaan spiritual tersebut serta mempertahankannya di depan publik. Dalam konteks ini pula, negara sesungguhnya memiliki hak untuk membatasi atau tidak, sangat tergantung pada dampak dari aliranaliran keagamaan tersebut, apakah membahayakan kehidupan masyarakat secara luas atau membahayakan dalam pengertian

10 Stanley Adi Prasetyo. Pemajuan HAM di Indonesia, dalam http://sejuk.org/kolom/ hak-asasimanusia/59-pnps-no-1-tahun-1965-dari-perspektif-

ham.html, diakses 13 Februari 2012. teologis dan keyakinan yang dianggap "teracuni" oleh munculnya kelompok, aliran atau sekte-sekte keagamaan dimaksud.

Ratifikasi Negara Indonesia atas dua perjanjian internasional tentang hak-hak manusia, yaitu Kovenan Internasional tentang Hak-hak Ekonomi, Sosial dan Budaya (International Covenant on Economic, Social and Cultural Rights/ ICESCR) dan Kovenan Internasional tentang Hak-hak Sipil dan Politik (International Covenant on Civil and Political Rights/ ICCPR) pada tahun 2005, menimbulkan konsekuensi terhadap pelaksanaan hak-hak asasi manusia. Hal ini karena negara ini telah mengikatkan diri secara hukum terhadap kovenan internasional tersebut. Dalam rangka itu pula, pemerintah telah melakukan kewajiban untuk mengadopsi perjanjian yang telah diratifikasi ini ke dalam perundang-undangan, baik yang dirancang maupun yang telah diberlakukan sebagai undang-undang. Di samping itu, pemerintah Indonesia juga memiliki kewajiban mengikat untuk mengambil berbagai langkah dan kebijakan dalam rangka melaksanakan kewajiban untuk menghormati (to respect), melindungi (to protect) dan memenuhi (to fullfil) hak-hak dasar setiap manusia (baca: warga negara Indonesia). Kewajiban ini semestinya juga diikuti dengan kewajiban pemerintah yang lain, yaitu untuk membuat laporan yang bertalian dengan penyesuaian hukum, langkah-langkah, kebijakan-kebijakan, dan tindakan-tindakan yang dilakukan. ${ }^{11}$

Panorama kebebasan politik yang membuka jalan bagi terpenuhinya empat kebebasan dasar tersebut, belum dinikmati oleh kelompok minoritas agama, termasuk kelompok minoritas dalam suatu agama. Para pemeluk agama-agama minoritas (seperti kaum Bahai) dan penganut agama/aliran kepercayaan (seperti kelompok Kaharingan, Sunda Wiwitan, dan sejumlah penghayat kepercayaan lainnya) tetap diperlakukan secara berbeda dan cenderung diskriminatif. Sejumlah daerah juga memberlakukan perda bermuatan syariah yang sangat bertentangan dengan konsep penghormatan kepada hak asasi manusia.

Intervensi terbatas oleh negara pada kebebasan eksternal dalam konteks penyebaran

\footnotetext{
${ }^{11}$ Adi Prasetyo. Pemajuan HAM di Indonesia.
} 
atau pelaksanaan agama, semestinya didasarkan pada alasan yang diperlukan dalam rangka untuk menjaga ketertiban umum, kesehatan dan moral masyarakat, kebebasan dan hak-hak fundamental orang lain, ketika ajaran agama atau aliran tertentu tersebut dianggap dapat membahayakan hak-hak paling mendasar bagi setiap orang di sekitarnya. Bentuk intervensi yang dalam batas diperbolehkan untuk dilakukan oleh negara adalah pada kebebasan eksternal, yang hal tersebut mesti dituangkan atau dinyatakan dengan undang-undang. Dalam hal ini, misalnya dapat dilihat alasan pemerintah New Mexico dalam melakukan pelarangan sekte Hari Kiamat ${ }^{12}$ pimpinan David Koresh, karena sekte ini dinilai dapat membahayakan nyawa orang lain dan nyawa para pengikutnya. Demikian juga larangan pemerintah Amerika Serikat terhadap sekte Children of God $^{13}$ karena dianggap berpotensi menimbulkan gangguan terhadap moral masyarakat. Pelarangan serupa juga dilakukan pemerintah

\footnotetext{
${ }^{12}$ Sekte Hari Kiamat pimpinan David Koresh adalah kelompok/sekte berdasarkan apokaliptisisme. Sekte agama ini menganggap mereka hidup di hari akhir seperti tertera pada kitab Injil. Koresh mengklaim dirinya sebagai nabi terakhir. Aksi sekte ini memanas selama pengepungan di Waco, Texas, pada 1993. Koresh menamakan markas kelompok pengikutnya 'Ranch Apocalypse'. Alih-alih hidup bersama pemimpinnya menunggu kiamat, sekte ini berperang dengan FBI. Sebanyak 76 anggota termasuk Koresh mati terbakar di dalam gedung. Lihat dalam http://teknologi.inilah.com /read/detail/ 1403302/inilah-nabi-sekte-hari-kiamatterkenal, diakses 10 Januari 2013.

${ }^{13}$ Children of God (COG) yang belakangan dikenal sebagai Family of Loves (Keluarga Kasih), Keluarga, dan kini Keluarga Internasional adalah sebuah gerakan agama baru yang dimulai pada 1968 di Huntington Beach, California, Amerika Serikat. Pemimpin sekte, David Berg, berkomunikasi dengan para pengikutnya melalui Surat-surat Mo (Mo Letters), yaitu surat-surat yang berisikan petunjuk dan nasihat tentang berbagai topik rohani dan praktis, hingga ia meninggal pada akhir 1994. Setelah kematiannya, jandanya, Karen Zerby menjadi pemimpin Keluarga. Kehidupan seksual yang bebas dari kelompok ini, penerbitan dan distribusi tulisan-tulisan, foto-foto dan video mereka yang menganjurkan dan mendokumentasikan kehidupan seksual antara orang dewasa dan anak-anak, serta seksualisasi anak-anak, menyebabkan munculnya berbagai laporan tentang hubungan seksual antara orang dewasa dan anak-anak. Baca lebih lanjut dalam http://id.wikipedia.org/ wiki/Children_of_God, diakses tanggal 10 Januari 2013.
}

Amerika terhadap sekte Heaven's Gate. ${ }^{14}$ Dengan demikian, pelarangan terhadap sekte atau aliran tersebut didasarkan pada adanya pertimbangan eksternal berupa bahaya bagi kehidupan masyarakat secara umum.

Dalam Komentar Umum No. 22 juga ditegaskan bahwa Pasal 18 ICCPR tidak mengijinkan adanya pembatasan apapun terhadap kebebasan berkeyakinan atau terhadap kebebasan untuk menganut atau menerima suatu agama atau kepercayaannya sesuai dengan pilihannya. Kebebasankebebasan ini dilindungi tanpa pengecualian. Dengan demikian, kebebasan internal atas hak ini tidak boleh dibatasi tanpa pengecualian.namun kebebasan ksternal boleh dilakukan pembatasan karena pertimbangan kemaslahatan berupa melindungi hak hidup pengikut atau masyarakat di sekitarnya, sebagaimana terjadi pada sekte Hari Kiamat maupun Children of God tersebut.

Kebebasan bergama yang merupakan hak sipil setiap orang, adalah prinsip yang kini telah diterima oleh hampir semua kalangan umat beragama sebagai norma universal. ${ }^{15}$ Ketakutan pemerintah akan munculnya kekacauan bila UU PNPS Nomor 1/Th 1965 dicabut, dapat dinyatakan telah menunjukkan bagaimana tidak dipahaminya tugas dan kewajiban pemerintah dalam mewujudkan penghormatan, perlindungan, dan pemenuhan HAM bagi warga negara yang seharusnya wajib dilindungi secara konstitusional. Dalam prinsip HAM, pemangku kepentingan bagi implementasi HAM adalah jajaran kepolisian dan aparat penegak hukum. Para pemangku kepentingan ini memiliki tanggung jawab besar bagi tegaknya hukum dan ketertiban (law and order) lainnya. Mereka juga harus didorong agar dapat bertindak secara layak, proporsional, dan tegas terhadap tindakan yang dilakukan oleh sejumlah orang yang

14 Heaven's Gate (Gerbang Surga) adalah kelompok/sekte keagamaan di Amerika yang banyak membuat kejutan, karena peristiwa bunuh diri massal terjadi akhir Maret 1997 di wilayah San Diego, California. Dalam peristiwa bunuh diri massal tersebut sebanyak 39 orang, 21 wanita dan 18 laki-laki ditemukan tewas. http://www.salahketik.com/beritaufo/hvgate.html, diakses 10 Januari 2013.

15 Lihat Ulil Abshar Abdalla, "Kebebasan Pilihpilih", dalam http://islamlib.com/id/ artikel/ ke-bebasan pilih-pilih, diakses 18 Februari 2012. 
melakukan penyerangan, penganiayaan, perampasan, dan perusakan harta-benda, sarana dan fasilitas orang lain, dengan mengatasnamakan "membela agama" dari penodaan. Semua bentuk aksi kekerasan ini apabila tidak dihentikan dengan efektif oleh Negara, maka akan dapat mengarah kepada "relegious prosecution", dan pembiaran yang mengarah kepada bentuk pelanggaran HAM by commission (pelanggaran dengan pembiaran) yang dilakukan negara.

Dalam konteks menghormati dan melindungi hak-hak sipil dan politik, ada dua jenis pelanggaran yang bertalian dengan kewajiban negara sebagai salah satu pemangku kepentingan, yakni: pertama, negara memiliki kewajiban untuk menghormati hak-hak manusia, tetapi negara justru melakukan tindakan yang dilarang atau bertentangan dengan ICCPR melalui campur-tangannya. Tindakan inilah yang kemudian disebut sebagai pelanggaran melalui tindakan (violation by action). Kedua, negara memiliki keharusan untuk terlibat secara aktif dalam rangka menjamin dan melindungi hak-hak sipil dan politik warga negaranya. Namun demikian, seringkali yang terjadi justru sebaliknya, yakni negara tidak melakukan apaapa atau tidak mengambil peran apapun, baik karena negara lalai maupun absen. Tindakan semacam inilah yang kemudian disebut sebagai pelanggaran melalui pembiaran (violation by omission). Ketiga, pemberlakukan ketentuan hukum yang secara substantif bertentangan dengan ICCPR. Pelanggaran model ini seringkali disebut sebagai bentuk pelanggaran melalui hukum (violation by judicial). Dalam konteks pelanggaran model terakhir ini, negara tidak menyediakan fasilitas konstitusional yang berupa infrastruktur pendukung atas langkahlangkah implementatif sebagai akibat atau hasil dari adanya ratifikasi berbagai perjanjian hak-hak manusia. Hal ini juga dapat dipandang sebagai sikap tidak mau (unwilling), abai, cuek, atau masa bodoh untuk berbuat sesuatu. Perilaku yang termasuk dalam katgori ini adalah bagaimana seharusnya semua aparatur pemerintah terutama yang berada pada "lingkungan" peradilan dan pengadilan, dituntut bisa menampilkan pola perilaku atau berperilaku yang mencerminkan amanat
ICCPR. Bahkan seringkali implementasinya tampak kurang memiliki signifikansi dan kurang memiliki efek positif bagi upaya penegakan hak-hak dasar kemanusiaan sebagaimana yang dimaksud dalam kovenan yang telah diratifikasi pemerintah Indonesia tersebut.

Kebebasan beragama merupakan salah satu hak dasar setiap individu yang mendapat jaminan konstitusional. Sila pertama Pancasila dan pasal 29 UUD 1945 dapat disebut sebagai contohnya. Namun demikian, laporan yang diberikan oleh SETARA Institute mengungkapkan bahwa pasal 29 UUD 1945 merupakan pasal yang menjadi landasan yuridis produksi berbagai perudang-undangan yang bersifat restriktif terhadap jaminan kebebasan beragama/berkeyakinan. ${ }^{16}$ Kendati demikian, masih ada beberapa terobosan konstitusional yang mendukung terjaminnya kebebasan beragama di Indonesia, yakni: pertama, hasil amandemen UUD 1945 yang dirumuskan dalam pasal 28 E UUD 1945, yang memberi penegasan bahwa ada jaminan kebebasan beragama bagi setiap orang dan tidak seorang pun berhak meniadakan atau memaksakan agama atau paham kegamaan tertentu kepada orang lain. ${ }^{17}$

Deklarasi Umum Hak Asasi Manusia (DUHAM) yang menjadi dasar bagi keharusan ditegakkannya kebebasan beragama ini dinyatakan bahwa:

"Setiap orang berhak atas kemerdekaan
berfikir, berkeyakinan dan beragama,
hak ini mencakup kebebasan untuk
berganti agama atau kepercayaan, dan
kebebasan untuk menjalankan agama
atau kepercayaan dalam kegiatan
pegajaran, peribadatan, pemujaan dan
ketaatan, baik sendiri maupun bersama-
sama dengan orang lain di muka umum
maupun secara pribadi".

Dalam pasal 28E amandemen UUD 1945, juga ditegaskan bahwa: 1)"Setiap orang bebas memeluk agama dan beribadat menurut agamanya, memilih pendidikan dan pengajaran, memilih pekerjaan, memilih

16 SETARA Institute, 2008, 85, dalam Rachman (ed.), Membela Kebebasan, h. xxviii.

${ }^{17}$ Rachman, Membela Kebebasan, xiv. 
164 | de Jure, Jurnal Syariah dan Hukum, Volume 6 Nomor 2, Desember 2014, hlm. 157-165

kewarganegaraan, memilih tempat tinggal di wilayah negara dan meninggalkannya, serta berhak kembali"; dan 2) "Setiap orang berhak atas kebebasan meyakini kepercayaan, menyatakan pikiran dan sikap, sesuai dengan hati nuraninya". Kalimat yang tercetak miring dalam ayat 2 pasal 28 E UUD 1945 tersebut, memberikan penegasan bahwa kebebasan beragama/berkeyakinan merupakan pilihan bebas sesuai dengan hati nurani seseorang yang harus dihormati dan tidak seorangpun atau institusi manapun dapat menghalangi, meniadakan atau memaksakan agama kepada seseorang. Kedua, munculnya Undang-undang No. 39/1999 tentang Hak Asasi Manusia (HAM); ketiga, ratifikasi yang dilakukan pemerintah atas Kovenan Internasional tentang Hak-hak Sipil dan Politik (ICCPR) melalui UU No.12/2005, yang memberi jaminan hak atas kebebasan berpikir, berkeyakinan dan beragama dalam kerangka yang lebih luas dan komprehensif. Dalam konteks ratifikasi mengenai persoalan kebebasan beragama ini, dapat dilihat pada ayat 1-4 pasal 18 dalam UU Nomor 12 tahun 2005 tentang Ratifikasi ICCPR sebagai berikut:

1. Setiap orang berhak atas kebebasan berpikir, keyakinan dan beragama. Hak ini mencakup kebebasan untuk menetapkan agama atau kepercayaan atas pilihannya sendiri, dan kebebasan, baik secara sendiri maupun bersama-sama dengan orang lain, baik di tempat umum atau tertutup, untuk menjalankan agama dan kepercayaannya dalam kegiatan ibadah, pentaatan, pengamalan, dan pengajaran.

2. Tidak seorang pun dapat dipaksa sehingga terganggu kebebasannya untuk menganut atau menetapkan agama atau kepercayaannya sesuai dengan pilihannya.

3. Kebebasan menjalankan dan menentukan agama atau kepercayaan seseorang hanya dapat dibatasi oleh ketentuan berdasarkan hukum, dan yang diperlukan untuk melindungi keamanan, ketertiban, kesehatan, atau moral masyarakat, atau hak-hak dan kebebasan mendasar orang lain.
4. Negara Pihak dalam Kovenan ini berjanji untuk menghormati kebebasan orang tua dan apabila diakui, wali hukum yang sah, untuk memastikan bahwa pendidikan agama dan moral bagi anak-anak mereka sesuai dengan keyakinan mereka sendiri.

Komentar Umum Komite HAM PBB yang merupakan penafsiran otoritatif atas ketentuan dalam Kovenan Internasional Hak Sipil dan Politik, menyatakan bahwa hak atas kebebasan beragama dan berkeyakinan pada dasarnya meliputi dua dimensi individual dan kolektif. Pasal ini memberikan perlindungan kepada individu maupun ketika di individu harus melakukannya bersama-sama dengan orang lain. Dengan demikian, sebuah kelompok keagamaan juga memiliki hak untuk melaksanakan kepercayaan/agama yang mereka yakini kebenarannya.

\section{Kesimpulan}

Kebebasan beragama dan penghormatan terhadap agama/kepercayaan orang lain sesungguhnya merupakan ajaran setiap agama. Karenanya membela kebebasan beragama dan menghormati agama/keyakinan orang lain, merupakan bagian integral dari nilai dan kualitas keberagamaan seseorang. Oleh sebab itu, jika kita menginginkan kebebasan yang sebenarnya, maka cara satu-satunya adalah dengan membiarkan orang lain memiliki kebebasan yang sama. ${ }^{18}$ Upaya lebih mendasar dan sangat monumental untuk menjamin perlindungan dan penegakan HAM, adalah melalui Perubahan UUD 1945. Perubahan konstitusi mengenai hak asasi manusia dibahas dan disahkan pada 2000, yaitu pada perubahan ke dua UUD 1945. Perubahan tersebut menghasikan ketentuan tentang hak asasi manusia dan hak konstitusional warganegara, yang semula hanya terdiri dari tujuh butir ketentuan, yang juga tidak seluruhnya dapat disebut sebagai jaminan konstitusional hak asasi manusia yang kini bertambah secara signifikan, menjadi 37 butir ketentuan. Ketentuan baru yang diadopsikan ke dalam

\footnotetext{
${ }^{18}$ Mohammad Imam Aziz, dalam Budhy Munawar Rachman (ed.), Membela Kebebasan Beragama, h. 1259 .
} 
Umi Sumbuluh, Aliran Sesat dan Gerakan Baru...| 165

UUD 1945 secara khusus diatur dalam Bab XA tentang Hak Asasi Manusia, mulai Pasal 28A sampai dengan Pasal 28J, ditambah beberapa ketentuan lainnya yang tersebar di beberapa pasal lainnya dalam UUD 1945. Karena itu, perumusan tentang hak asasi manusia dalam konstitusi Indonesia saat ini dapat dikatakan sangat lengkap dan menjadikan UUD 1945 sebagai salah satu konstitusi di dunia yang paling lengkap

\section{DAFTAR PUSTAKA}

Abdalla, Ulil Abshar. "Kebebasan Pilih-pilih", dalam http://islamlib.com/id/ artikel/ kebebasan -pilih-pilih, diakses 18 Februari 2014.

Aziz, Mohammad Imam, dalam Budhy Munawar Rachman (ed.), Membela Kebebasan Beragama, hlm. 1259.

Harian Umum Jawa Pos, 16 Nopember 2007.

Harian Umum Jawa Pos, 30 Oktober 2007.

Harian Umum Jawa Pos, 31 Oktober 2007

Harian Umum Jawa Pos, 7 Nopember 2007.

http://id.wikipedia.org/ wiki/Children_of_God, diakses tanggal 10 Januari 2014.

http://teknologi.inilah.com/read/detail/1403302 inilah-nabi-sekte-hari-kiamat-terkenal,

diakses 10 Januari 2013.

http://www.salahketik.com/beritaufo/hvgate.ht

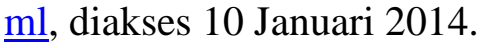

http://www.setara-

institute.org/id/content/kondisi-

kebebasan-beragama-dan-berkeyakinan-mid-2013, dikases 12 Agustus 2013.

http://indonesian.jakarta.usembassy.gov/news/

keyreports_irf-2012-id.html, diakses 12

Agustus 2013.

Prasetyo, Stanley Adi. Pemajuan HAM di

Indonesia, dalam http://sejuk.org/ kolom/

hak-asasi-manusia/59-pnps-no-1-tahun-

1965-dari-perspektif-ham.html, diakses

13 Februari 2014.

Reportase Sore", Trans TV, tanggal 31 Juli 2009. memuat ketentuan perlindungan hak-hak asasi manusia. Dengan konstitusi ini, diharapkan tidak akan ada lagi kelompk-kelompok yang merasa "paling berhak" dalam menilai sesat tidaknya suatu aliran/ajaran tertentu secara sewenang-wenang, sehingga tetap ada penghormatan terhadap hak asasi yang mereka miliki.

Rachman, Budhy Munawar Rachman (ed.) Membela Kebebasan Beragama. Jakarta: LSAF-Paramadina, 2010.

Sumbulah, Umi. Konfigurasi Fundamentalisme Islam. Malang: UIN Malang Press, 2009.

UU PNPS Nomor 1 tahun 1965 tentang Pencegahan Penyalahgunaan Dan/Atau Penodaan Agama. 